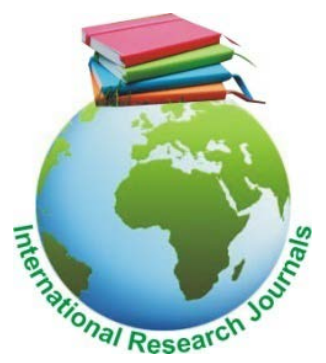

African Journal of Food Science and Technology (ISSN: 2141-5455) Vol. 10(1) pp. 1-4, Jan, 2019

DOI: http:/dx.doi.org/10.14303/ajfst.2019.001

Available online https://www.interesjournals.org/food-science-technology.html

Copyright (C2019 International Research Journals

Full Length Research Paper

\title{
Thermal degradation kinetics of hemaglutinin in African yam bean (Sphenostylis stenocarpa) seeds using partial cooking method
}

\author{
Iwuamadi God's Battle-Axe Izuchukwu*, Clement Owoicho Momoh, Benbella Msugh Iorliam
}

Department of Food Science and Technology, University of Agriculture, Makurdi, Nigeria.

*Corresponding Author Email: izunnaiwu@gmail.com

\begin{abstract}
In this study, the thermal degradation kinetics of hemagglutinins in African yam bean (Sphenostylis stenocarpa) seeds during partial wet cooking was investigated. Heat treatments were carried out at different temperatures of $80,85,90$, and $95^{\circ} \mathrm{C}$ over a period of 10 to 40 minutes at isothermal conditions. The degradation of hemagglutinin was adequately modelled by the fractional conversion model and Arrhenius equation. There was a progressive decrease in hemagglutinin activity for each thermal treatment as the cooking time increased. High values of Coefficient of linear regression; $R^{2}$ ranging from $0.795-0.931$ confirmed the degradation to follow the first order thermal kinetics. Thermal treatment of $95^{\circ} \mathrm{C}$ for 40 minutes was sufficient to reduce $82 \%$ of hemagglutinin activity in African yam bean seeds.

KEY WORDS: African yam beans, Hemagglutinin, Thermal degradation.
\end{abstract}

\section{INTRODUCTION}

Kinetic studies help food process engineers and scientists to optimize processing systems and design processes, to improve and optimize existing processes and develop control systems for processing operations in terms of reaction rates. These studies help to predict how quick the reaction mixture will attain equilibrium condition, and also in predicting the reaction mechanism (Kavita et al., 2006).

African Yam Bean (AYB) is an herbaceous leguminous plant occurring throughout tropical Africa. It is grown as a minor crop in association with yam and cassava. AYB serves as security crop; it has the potential to meet year round protein requirements if grown on a large scale (Aburime, 2012). African Yam Bean (AYB) is highly nutritious with high protein, mineral and fibre content, its protein content is reported to be similar to that of some major and commonly consumed legumes (Nwosu, 2013). Its amino acid profile is comparable if not better than those of cowpea, soy bean and pigeon pea (Aburime, 2012). Aside the nutritional benefits of AYB, the seeds are encumbered by the presence of anti- nutrients (Udeogu and Awuchi, 2016). Habtamu and Negussie (2014) defined anti-nutrients as chemicals which have been evolved by the plants for their own defense, among other biological functions and reduce the maximum utilization of nutrients especially proteins, vitamins, and minerals, thus preventing optimal exploitation of the nutrients present in the food and decreasing the nutritive value. Lectin, also called hemagglutinin is one of the anti-nutrients found in AYB seeds (Udeogu and Awuchi, 2016). Lectins may be inactivated, destroyed or drastically reduced by some processing operation, such as cooking (El-Adawy, 2002) and malting (El-Adawy, 2002).

Importantly, hemagglutinin can be detoxified by several processing method such as soaking, cooking, boiling, germination, autoclaving, fermentation, sprouting, genetic manipulation and other processing methods, which however may interfere with the level of protein and fibre contents used as indicator of high nutritive value as reported by Apata and Ologhobo (1994). However, Betch et al. (2005) reported that while fermentation can substantially improve the nutritional quality of AYB and reduce loses due to thermal influences of most food values, roasting was found to have greater efficiency in the elimination or reduction of the levels of phytate available in AYB and boiling seemed to eliminate hemagglutinin more efficiently when compared with roasting and others. Information on heat processing and kinetics of degrading the toxicity of hemagglutinin in AYB is insufficient (Beckley et al., 2012), hence the aim of this study. 


\section{MATERIALS AND METHODS}

The brown (dark coloured) African yam bean (Shpenostylis stenocarpa) used for the work was obtained from a local market (Wurukum market) in Makurdi, Benue state. Heat treatments were carried out at different temperatures of $80,85,90$, and $95^{\circ} \mathrm{C}$ over a period of 10 to 40 minutes in a water bath (DK420) using standard methods, further -more, determination of hemagglutinin level was done using standard methods (AOAC, 2012).

\section{Kinetic Calculation}

A general reaction rate expression for the degradation kinetics can be written as follows: (Tola and Ramaswamy, 2015).

$$
-\frac{d[C]}{d t}=k[C]^{n}
$$

Where $\mathrm{C}$ is the quantitative value of the concentration of the degraded molecule under consideration, $k$ is the reaction rate constant, and $n$ is the order of the reaction. The equation for first order rate kinetics can be obtained by the integration of Eq. (1) as

$\ln \left([C]_{0} /[C]_{t}\right)=-k t$

Where $[c]_{0}$ is the concentration of the reactants under consideration at time 0 , and $[c]_{t}$ is the value after reaction (heating) time t.

According to Tola and Ramaswamy (2015), the intensity of heat on degradation of most nutrients in foods can be determined using the Arrhenius kinetic model. The effect of temperature in absolute form on the reaction rate constant $k$ is explained by Arrhenius, in Eq. ( 3 and 4).

$k=A_{o} \exp \left(-\frac{E_{a}}{R T}\right)$

$\ln k=\ln k_{\text {Tref }}+\left[\frac{E_{a}}{R}\left\{\frac{1}{T_{\text {Tref }}}-\frac{1}{T}\right\}\right]$

Where, $k_{\text {Tref }}$ is reaction rate constant at reference temperature, $E_{a}$ is the activation energy $(\mathrm{kJ} / \mathrm{mole})$, and $\mathrm{R}$ the molar gas constant ( $\left.8.314 \mathrm{~J} \mathrm{~mole}^{-1} \mathrm{~K}^{-1}\right), \mathrm{T}$ temperature (K) at time $\mathrm{t}$.

The graph Ink versus $\frac{1}{T}$ will give us a linear line from which the inverse slope is used to calculate the $E_{a}$ required for the reaction.

Slope $=\frac{E a}{2.303 R}$

\section{RESULTS AND DISCUSSION}

Quantity of Hemagglutinins in African Yam Bean Flour at Isothermal Conditions

Table 1 shows the effect of wet-heat treatment at different temperatures $\left(80-95^{\circ} \mathrm{C}\right)$ for different time periods on the resultant concentration of Hemagglutinins. The initial concentration of Hemagglutinins in African Yam Bean flour found in this study was $1.205 \mathrm{mg} / 100 \mathrm{~g}$, whereas the Hemagglutinin activity of African Yam Bean flour reported by El-Adawy (2002) was $6.22 \mathrm{mg} / 100 \mathrm{~g}$. The variation in the content may be due to varietal difference as reported by Abioye et al., (2015), these include different cultivars of AYB planted on soils with different soil nutrient makeup.

Furthermore, there was a progressive decrease in Hemagglutinin activity for each thermal treatment as the cooking time was increased. This clearly indicates that Hemagglutinins are relatively heat labile constituents (Qayyum et al., 2012). This trend in degradation obviously indicates the degradation to follow a first order kinetics. Similar experiment by Kavita et al., (2006) showed the degradation of Saponins in Soya bean flour to follow the first order kinetics.

The reduction of Hemagglutinin during heating suggest that they would be a great reduction in the ability of the sugar binding proteins to bind and agglutinate (Nwosu, 2013). While heating at $95^{\circ} \mathrm{C}$ for $40 \mathrm{~min}$ reduced hemagglutinin levels by $82 \%$ (Table 2). Nwosu (2013) reported that soaking and malting for $48 \mathrm{~h}$ reduced Hemagglutinin levels by $49 \%$ and $38 \%$ respectively. Acceptable level of Hemagglutinin in food and food products as approved by the U.S department of Agriculture (2007) ranges from 0.1 to $0.33 \mathrm{mg} / 100 \mathrm{~g}$, hence reduction at $95^{\circ} \mathrm{C}$ for 40 min gives the best level of Hemagglutinin with minimal negative effect.

Table 1. Effect of Heating on Hemagglutinin (mg/100 g) in AYB Flour at Various Temperatures

\begin{tabular}{|c|c|c|c|c|}
\hline \multirow{2}{*}{$\begin{array}{c}\text { Time } \\
(\mathbf{m i n})\end{array}$} & $\mathbf{4}$ Temperature ('C) \\
\cline { 2 - 5 } & 80 & $\mathbf{8 5}$ & $\mathbf{9 0}$ & $\mathbf{9 5}$ \\
\hline 10 & $1.074^{\mathrm{a}} \pm 0.02$ & $0.993^{\mathrm{a}} \pm 0.02$ & $0.724^{\mathrm{a}} \pm 0.02$ & $0.520^{\mathrm{a}} \pm 0.02$ \\
\hline 20 & $1.052^{\mathrm{a}} \pm 0.01$ & $0.990^{\mathrm{a}} \pm 0.02$ & $0.522^{\mathrm{b}} \pm 0.02$ & $0.498^{\mathrm{a}} \pm 0.02$ \\
\hline 30 & $0.926^{\mathrm{b}} \pm 0.02$ & $0.715^{\mathrm{b}} \pm 0.01$ & $0.400^{\mathrm{c}} \pm 0.02$ & $0.336^{\mathrm{b}} \pm 0.03$ \\
\hline 40 & $0.613^{\mathrm{b}} \pm 0.02$ & $0.414^{\mathrm{c}} \pm 0.02$ & $0.382^{\mathrm{c}} \pm 0.03$ & $0.215^{\mathrm{c}} \pm 0.02$ \\
\hline LSD $_{0.05}$ & 0.03 & 0.09 & 0.05 & 0.07 \\
\hline
\end{tabular}

-Values are mean \pm Standard deviation of triplicate determination. Mean Values with same superscript letters on the same column are not significantly different $(p<0.05)$

-The Hemagglutinin content of the raw AYB flour was found to be $1.205 \pm 0.02$ $\mathrm{mg} / 100 \mathrm{~g}$.

LSD=Least Significant Difference

Thermal Degradation Kinetics of African Yam Bean (AYB) Hemagglutinin after Cooking Treatments.

In order to find the kinetic model that better fits the obtained experimental data points, the two-step method was used as a first approach (Goncalves et al., 2010). Considering each Hemagglutinin parameter, a regression analysis was applied, in a first step, for each isothermal experiment to calculate the corresponding reaction rate 
Table 2. Percentage Reduction of Hemagglutinin $(\mathrm{mg} / 100 \mathrm{~g})$ in AYB at Various Temperature and Time

\begin{tabular}{|c|c|c|c|c|}
\hline \multirow{2}{*}{ Temp. ( $\left.{ }^{\circ} \mathbf{C}\right)$} & \multicolumn{4}{|c|}{ Percentage Reduction } \\
\cline { 2 - 5 } & $\mathbf{1 0} \mathbf{~} \mathbf{i n}$ & $\mathbf{2 0} \mathbf{~}$ in & $\mathbf{3 0}$ $i n$ & $\mathbf{4 0}$ in \\
\hline 80 & 11 & 13 & $\mathbf{2 3}$ & 49 \\
\hline 85 & 18 & 18 & 41 & 66 \\
\hline 90 & 40 & 57 & 67 & 68 \\
\hline 95 & 57 & 59 & 72 & 82 \\
\hline
\end{tabular}

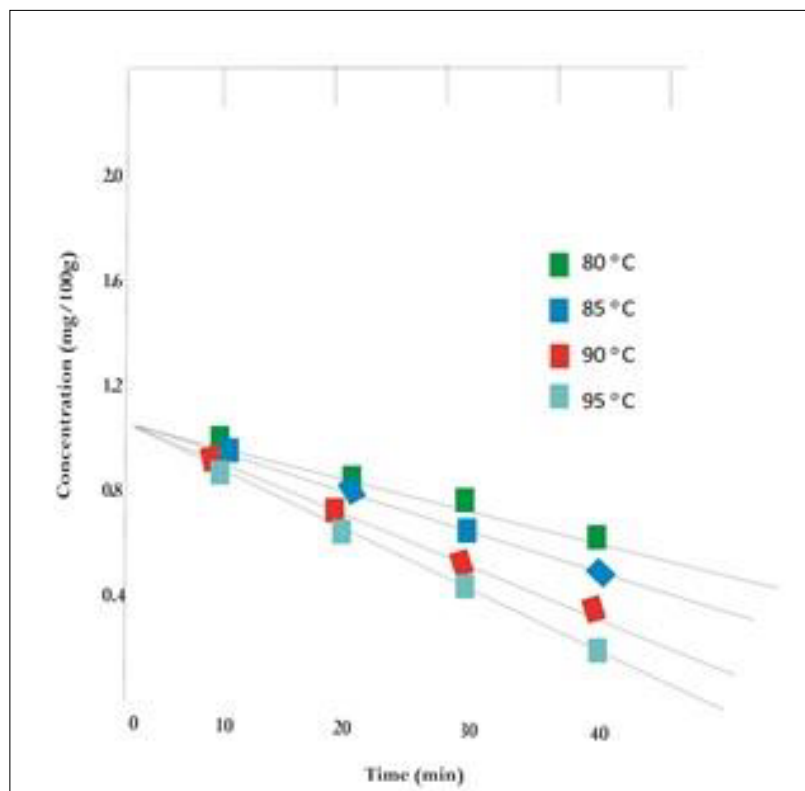

Figure 1. First Order Plot of Hemagglutinin degradation in AYB seed flour at $80,85,90$ and $95^{\circ} \mathrm{C}$.

constant.

Accordingly, $\ln \left([\mathrm{C}]_{0} /[\mathrm{C}]_{t}\right.$ )' was plotted vs. t, from which rate constant, $\mathrm{k}$ was calculated as the slope of the linear plot. Figure 1 shows the first order reaction model (Eq. (1)) applied to the hemagglutinin values, respectively.

Table 3 shows the Rate Constants $(k)$ and regression coefficient $\left(R^{2}\right)$ of Hemagglutinin degradation in AYB Flour. The rate constants increased with a corresponding increase in temperature. This is because temperature increase the rate of reaction. Similar findings have been reported by Kavita et al., (2006). High values of correlation coefficient ranging from 0.795 to 0.931 confirmed the degradation to follow the first order kinetics.

In order to make a better estimate of the kinetic parameters, a one-step non-linear regression was applied to all data (Table 4). Based on the examination of the residuals, this proved to be the most adequate model, hence the distribution of residuals has no visual tendency (were randomly distributed around zero).

Estimated activation energies and rate constants at the reference temperature of $88^{\circ} \mathrm{C}$ and corresponding $95 \%$ $(p<0.05)$ confidence intervals are reported in Table 3. An inversely proportional relationship was found to exist between the activation energies and rate constant at $88^{\circ} \mathrm{C}$ (reference temperature). Similar results were obtained by Goncalves et al., (2010) who studied peroxidase inactivation of Pumpkin during blanching and found that increase in Activation energy led to decrease in the reaction rate constant at $88^{\circ} \mathrm{C}$.

Table 3. Rate Constants $(k)$ and Regression Coefficient $\left(R^{2}\right)$ of Hemagglutinin Degradation in AYB Seed Flour

\begin{tabular}{|c|c|c|c|}
\hline Temperature $\left({ }^{\circ} \mathbf{C}\right)$ & $\begin{array}{c}\text { Rate Constant, } \boldsymbol{k} \\
\left(\mathbf{m i n}^{-1}\right)\end{array}$ & $\begin{array}{c}\text { Regression } \\
\text { coefficient( } \mathbf{R}^{\mathbf{}} \text { ) }\end{array}$ & $\begin{array}{c}\text { Standard } \\
\text { error }\end{array}$ \\
\hline 80 & 0.891 & 0.795 & 0.116 \\
\hline 85 & 0.943 & 0.88 & 0.102 \\
\hline 90 & 0.948 & 0.888 & 0.064 \\
\hline 95 & 0.965 & 0.931 & 0.046 \\
\hline
\end{tabular}

Table 4. Kinetic Parameters for Hemagglutinin degradation of AYB using onestep Non-linear Regression Method

\begin{tabular}{|l|c|c|c|c|c|}
\hline Samples & $\mathbf{E}_{\mathbf{a}}(\mathbf{K J} / \mathbf{m o l})$ & $\mathbf{K}_{88}{ }^{0} \mathbf{~}\left(\mathbf{m i n}^{-1}\right)$ & $\mathbf{C}_{\mathbf{0}}$ & $\mathbf{C}_{\mathbf{r}}$ & $\mathbf{R}^{\mathbf{2}}$ \\
\hline A & $102 \pm 3.4$ & $0.946 \pm 0.01$ & $1.052 \pm 0.02$ & $0.615 \pm 0.02$ & 0.795 \\
\hline B & $119 \pm 2.1$ & $0.906 \pm 0.02$ & $0.993 \pm 0.09$ & $0.414 \pm 0.04$ & 0.88 \\
\hline C & $123 \pm 3.6$ & $0.821 \pm 0.01$ & $0.724 \pm 0.01$ & $0.383 \pm 0.01$ & 0.888 \\
\hline
\end{tabular}

Activation Energies and Rate constants at Reference Temperature of $88^{\circ} \mathrm{C}$ and Corresponding 95\% Confidence Interval

\section{CONCLUSION}

The study reveals that thermal treatment of $95^{\circ} \mathrm{C}$ for 40 minutes was sufficient to reduce $82 \%$ of hemagglutinin activity with minimal negative effect in African yam bean seeds. This can also be achieved with dissimilar optimal temperatures for other hemagglutinin rich flour sources. The values of the regression coefficient, $\mathrm{R}^{2}$ (ranged between 0.795-0.931) showed the reliability of the suggested model. The Arrhenius model described the temperature dependence of the reaction rate constant of all the considered parameters

\section{REFERENCES}

Abioye VF, Olanipekun BF, Omotosho OT (2015). Effect of Varieties on the Proximate, Nutritional and Antinutritional Composition of Nine Variants of African Yam Bean Seeds (Sphenostylis stenocarpa). Donn. J. Food. Sci. Tech. 1(2): 017-021.

Aburime LC (2012). Effect of the various processing methods on the chemical composition of african yam bean (Sphenostylis stenocarpa) flours and organoleptic characteristics of their gruels. A project report submitted in partial fulfilment of the requirements for the award of master's degree in human nutrition. Department of home science, Nutrition and Dietetics, University of Nigeria, Nsukka. 
AOAC (2012). Official Methods of Analysis of AOAC international. In: William Horwitz, and Dr. George Latimer (19th eds). AOAC International, Gaithersburg, Maryland, USA.

Apata DF, Ologhobo AD (1994). Biochemical evaluation of some Nigerians legume seeds. Food. Chem. 49(4):333-338.

Beckley I, Joseph K (2012). Genetic assessment of three colour variants of african yam bean (Sphenostylis stenocarpa) commonly grown in the midwestern region of Nigeria. Int. J. Mod. Bot. 2(2): 13-18.

Betche T, Azeke M, Buening-Pfaue H, Fretzdorff B (2005). Food safety and security: Fermentation as a tool to improve the nutritional value of african yam bean, Conference proceedings of International Agricultural Research for Development.1-5.

El-Adawy TA (2002). Nutritional composition and antinutritional factors of chickpeas (Cicer arietinum L.) undergoing different cooking methods and germination. Plant. Foods. Hum. Nutr. 57(1): 83-97.

Goncalves EM, Pinheiro J, Abreu M, Brandao TRS, Silva CLM (2010). Modelling the kinetics of peroxidase inactivation, colour and texture changes of pumpkin (Cucurbita Maxima L.) during blanching. J. Food. Eng. 81(4): 693-701.

Habtamu Fekadu Gemede, Negussie Ratta (2014).
Antinutritional factors in plant foods: Potential health benefits and adverse effects. Int. J. Nutr. Food. Sci. 3(4):284-289.

Kavita MT, Rekha SS, Radha VJ, Aniruddha BP (2006). Kinetics of degradation of saponins in soybean flour (Glycine max.) during food processing. J. Food. Eng. 76(3): 440-445.

Nwosu JN (2013). Evaluation of proximate compositions and antinutrient properties of AYB (Sphenostylis stenocarpa). using soaking and malting treatment. Int. J. Bas. Appl. Sci. 2(4): 157-169.

Qayyum MMN, Butt MS, Anjum FM, Nawaz H (2012). Composition analysis of some selected legumes for protein isolates recovery. J. Ani. Plant. Sci. 22(4): 11561162.

Tola BY, Ramaswamy HS (2015).Temperature and high pressure stability of lycopene and vitamin $\mathrm{c}$ of watermelon juice. Afri. J. Food. Sci. 9(5): 351-358

Udeogu E, Awuchi CG (2016). Effect of some processing methods on hemagglutinin activity of lectin extracts from selected grains (cereals and legumes). Int. J. Adv. Aca. Res. 2(12): 24-59.

USDA (2007). U.S. Department of Agriculture, Agricultural Research Service: USDA National Nutrient Database for Standard Reference. 